DOI 10.4467/2543733XSSB.17.039.8337

JACEK WOJNICKI

Institute of European Studies

University of Warsaw

\title{
THE EVOLUTION OF THE PRESIDENCY IN THE POST-YUGOSLAV COUNTRIES IN THE 1990s - THE NON-INSTITUTIONAL OR INSTITUTIONAL ELEMENT OF THE DEMOCRATIC SYSTEM
}

Keywords: presidency, postcommunist states, desintegration of Yugoslavia, democratization, autoritarian

This article is devoted to the analysis of the formation of state leadership in the states created after the breakup of the Yugoslav federation. The presidency was quite a new political solution, it did not occur during the first Yugoslavia (1918-1941) nor, for obvious reasons, before World War I (lack of the state system, or the monarchical form of state - the cases of Serbia and Montenegro). The formation of new political and social institutions at the beginning of the 1990s was related to the functioning of the Yugoslav state on the one hand, and to the observation and perception of external solutions, which did not always fit in the political system of a Balkan state, on the other.

The only tradition of presidency in Yugoslavia is based on the experiences related to Josip Broz-Tito, a politician that was ruling the country from 1944 until May, 1980¹.

1 see A. B i g g in i, F. Gu i da, Pół wieku realnego socjalizmu, Rzeszów 1998; D. B il a n d ž ić, Historija Socijalističke Federativne Republike Jugoslavije. Glavni procesi 1918-1985, Zagreb 1985; Z. B r z e zi ń s ki, Jedność i konflikty, Londyn 1964; F. F ejtő, A History of the People's Democraciep. Eastern Europe Since Stalin, New York, Washington, London 1971; R. L. Wolff, Balkans in Our Times, Cambridge, Massachusetts 1956; B. Jelavi c h, Historia Bałkanów, tom II: Wiek XX, Kraków 2005; L. P o d h or o d e c ki, Jugosławia. Dzieje narodów, państw i rozpad federacji, Warszawa 2000; R. S t a a r, Communist Regimes in Eastern Europe, Stanford 1982; M. Tanty, Bałkany w XX wieku. Dzieje polityczne, Warszawa 2003; W. Wa 1 k i e w i c z, Jugosławia. Wspólny byt i rozpad. Historia państw świata w XX wieku, Warszawa 2000. 
The presidency was introduced to the political system of Yugoslavia in January 1953, and established in a new constitutional law ${ }^{2}$. As a Yugoslav expert on constitutional matters commented in the mid-1950s:

The state system of the present Yugoslavia differs significantly from the one approved in the constitution in 1946. The point is not to reject, but to refine and permanently improve the old and outdated forms with new rules, in line with the overall economic, political and social development of the socialist community and its socialist democracy ${ }^{3}$.

It was after the break-up of close relations with the ally - the USSR in 1948 and while searching an own path of development. The role of the presidency was to institutionalize the personal power of Josip Broz-Tito, who combined it with the leadership of the Communist Party (since November 1952, it became the League of Communists of Yugoslavia $)^{4}$, however, at the same time it was not supposed to demolish the main structure of the political system based on the rule of the communist group. A Polish historian Marian Zacharias rightly remarks:

however, it is again necessary to reiterate the opinion that the real supreme power belonged to Tito and his closest associates. The President's office creation and entrusting it to this politician was a confirmation of his role and political significance in the country ${ }^{5}$.

In the resolution adopted in January 1953, the president was also the Chairman of the Federal Executive Council (the federal government). The Constitution specified that the president was elected for a term of the Federal Parliament (Skupština) with a possibility of appeal before the expiry of that period. President was, equally to other members of the Federal Executive Council, responsible for work of the Federal Executive Council to the Federal Parliament 6 .

The Skupština (Federal Assembly) at a joint meeting of all the chambers chose the president of Yugoslavia. Candidates for the president's office might be registered in the Parliament by a group of its members (a minimum of 30 members) as their own initiative or on the basis of the proposal of the Union Committee of a mass social-political organization such as the Socialist Working People's League of Yugoslavia. The president was elected by ballot. A resolution on the election or dismissal of the president (there was such a constitutional possibility) was taken by a majority of the total number of deputies ${ }^{7}$.

It was the Yugoslav Constitution of 1963 that established the vice president's office with a permanent mandate, that in the absence of the president would have replaced him in the head of state role. The constitutional regulations extended the usual rights of the

2 see Ustawa o podstawach ustroju spolecznego i politycznego Federacyjnej Ludowej Republiki Jugosławii z 3 stycznia 1953 roku, [w:] Konstytucja Federacyjnej Ludowej Republiki Jugosławii, Warszawa 1957; D. Rus in ov, The Yugoslav Experiment 1948-1974, Berkeley and Los Angeles 1978, p. 70 et seq.

${ }^{3}$ see J. D żor d z e w i c z, Ustrój państwowy Federacyjnej Ludowej Republiki Jugosławii, [w:] Ekonomia i polityka Jugosławii. Zbiór artykułów, Warszawa 1957, p. 64.

${ }^{4}$ see K. Č a v o šk i, Tito. Tehnologika vlasti, Beograd 1990.

5 see M. J. Z a charia s, Komunizm, federacja, nacjonalizmy. System władzy w Jugostawii 1943-1991. Powstanie, przeksztatcenia, rozkład, Warszawa 2004, p. 149.

${ }^{6}$ see E. Mizers ki, Jugosłowiański system przedstawicielski 1918-1990 (w zarysie), Toruń 1999, p. 70.

${ }^{7}$ see T. Szy mczak, Organy władzy i administracji europejskich państw socjalistycznych, Warszawa 1970, p. 176. 
vice president - the president could entrust his deputy to perform certain functions on his behalf. The vice president was elected by the federal parliament immediately after the presidential election and in the same manner. After the repeal of this position in April 1967, it was recorded in the constitutional regulation that the president's deputy was the chairman of the Federal Parliament ${ }^{8}$. The vice-president position was introduced for an ambitious politician - Alexander Rankovic, and was repealed after his resignation in the summer of 1966. The creation of political positions or institutions for specific groups of influence or politicians is very characteristic. Changes at the top of the line of power make it necessary to correct the model of the highest state authority structure?

The establishment that reflected the new tendencies at the turn of the 1960s and 1970s in Yugoslav constitutionalism was the creation of the Presidium of the Socialist Federal Republic of Yugoslavia. The establishment of the Presidium in 1971 was supposed to be an institutional form of addressing the matter of succession of Josip Broz-Tito, the Yugoslav leader at that time. The Presidium had to meet at least two key conditions in order to fulfil its political role in a federal state, which Yugoslavia had become since 1946: firstly, to enjoy the trust of its component members, but also to be functional at the same time, capable of renouncing particular republican interests in the name of the superior federal interest ${ }^{10}$. The difficulty of fulfilling these conditions, or even the impossibility, was verified by the later history of the Yugoslav state, after death of its leader in May, 1980. Such a task resembled the legendary challenge of squaring the circle. As Anglo-Saxon historians have rightly pointed out:

political solutions prepared for Tito's successors that were supposed to indicate the way of election of the highest state and party authorities have led to further undermine and decay of the federal structures. Tito, who did not succeed in identifying a truly "Yugoslav" successor and who realized that longer governance of a Serb or Croatian would be unacceptable, announced "permanent principles" of collective leadership in October $1978^{11}$.

The constitutional rights and duties of the president were almost the same as mandate of the Presidium of the Socialist Federal Republic of Yugoslavia (SFRY). The president's competence was primarily regarding the traditional power of the head of state which was: representing the state abroad and in the country, proclamation of laws and decrees. At the same time, the President was the chairman of the SFRJ Presidium, the Chief of the National Armed Forces and chairman of the National Defense Council. It was also a task of the head of state to report to the Parliament on the internal situation in the country, as well as on foreign policy, and to submit solution proposals of particular issues for the Parliament's consideration ${ }^{12}$.

${ }^{8}$ see T. S zy m c za k, Ewolucja instytucji prezydenta w socjalistycznym prawie państwowym, Łódź 1976, p. 43; D. Rus in ov, The Yugoslav Experiment 1948-1974, Berkeley and Los Angeles 1978, p. 156 et seq.

9 see B. Jelavich, Historia Bałkanów, tom II Wiek XX, p. 406-407 oraz K. Č avoški, Tito. Tehnologika vlasti, p. 45; D. Rusinov, The Yugoslav Experiment 1948-1974, Berkeley and Los Angeles 1978, p. 183 et seq.

${ }^{10}$ see J. C i e m ni ew s ki, System delegacki na tle ewolucji ustroju politycznego Socjalistycznej Federacyjnej Republiki Jugosławii, Wrocław 1988, p. 53.

${ }^{11}$ see J. R. Weg s, R. La d r e ch, Europa po 1945 roku. Zarys historii, Warszawa 2008, p. 348.

12 see E. Zi elińs ki, Skupsztina SFRJ, Warszawa 1978, p. 88. 
As a Polish expert on Balkan affairs commented on the death of the Yugoslav leader:

he passed away after 35 years of unlimited power. Tito, like many of the world's politicians, died believing in his well-fulfilled duty, being concerned about the future of Yugoslavia after his death. The evidence for that were his talks and discussions with state and party authorities in the last decade of December $1979^{13}$.

At this point it is worth mentioning what an American historian of the Balkan region of Europe noted. He summarized the period of Tito's reign and his political heritage in the following words:

Naturally, the Communist governance was not only a sequence of failures. They have led to the transformation of a typically agricultural country into a medium-industrialized one, without much Stalinism involved. In terms of this transformation, the Yugoslav socialist democracy fulfilled its promises, but in the general overview there were failures that counted. There was never a "market socialism" understood as a stable distribution of competencies between the party and independent companies operating solely on the basis of profit and loss matters. "Participatory democracy" was nothing but an empty slogan. The economic collapse and lack of democratic structures that would allow the Federation to evolve, effectively killed Yugoslavia ${ }^{14}$.

Such a practice concerning the position of president existed at the beginning of the 1990s. The political transformation of the late 1980s resulted in the creation of a new political order in Yugoslavia, and also in the individual Yugoslav republics ${ }^{15}$. It seems appropriate to refer to Robert Kaplan's opinion in the context of political and social changes in the post-Yugoslav countries:

the counter-revolution in Eastern Europe also included Yugoslavia. However, as social dissatisfaction spread horizontally putting various social groups against each other, and not vertically, then it would have aimed at the communist power in Belgrade. Taking this into account it is easier to understand why the path of change in Yugoslavia was more sparse and less visible from the beginning. That is why the outside world saw it only in 1991 when the fights started in Yugoslavia ${ }^{16}$.

It is characteristic that the union authorities led by Ante Markovic (since March 1989 the head of the Executive Council) were too weak to impose the scenario of political change within the entire Yugoslav state on other republics. The weakness of the federal institutions was accompanied by the progressive crisis in the offices of government and the party, one of the best examples of this complex and difficult situation was interruption of the 14th Extraordinary Congress of the Union of Yugoslav Communists in January 1990,

13 see A. Ko s e s ki, W bałkańskim tyglu, Pułtusk 2002, p. 171.

${ }^{14}$ see L. Holm e s, Jugosławia. Historia w zarysie, Kraków 2011, p. 185.

15 see M. J. Z a c h a ri a s, Ustrój Jugosławii w latach 1974-1980: przesłanki dezintegracji i późniejszego rozpadu państwa, „Studia z Dziejów Rosji i Europy Środkowo-Wschodniej”, T. 36 z 2001 r., p. 159-187 oraz S. P. R a m e t, Balkan Babel. The Disintegration of Yugoslavia form the Death of Tito to Ethnic War, Westwiew Press 1996, p. 8 et seq.; I. Vejv oda, Yugoslavia 1945-1991-from Decentralization Without Democracy to Dissolution, [in:] Yugoslavia and After. A Study in Fragmentation, Despair and Rebirth, [ed.] D. A. Dyker and I. Vejvoda, London and New York 1996, p. 15 et seq.

${ }^{16}$ see R. D. Ka a la n, Bałkańskie upiory. Podróż przez historię, Wołowiec 2010, p. 41. 
that was stopped in the atmosphere of quarrels and disputes ${ }^{17}$. In this case the changes took place according to scenarios of the individual republics ${ }^{18}$.

The key moment in the history of the Yugoslav Federation was 1990, also because that year the first separate parliamentary elections were held in each republic. At this point, it is worth emphasizing that the general election to the Skupsztina was no longer held (the last one took place in June 1986) ${ }^{19}$.

In April and May in 1990 there were elections held for the Republican Parliament in Slovenia, then in May 1990 to the Sabor (the name of the Republican Parliament in Croatia). The next republics elected their legislative authorities in the fall - in November 1990 Bosnia and Herzegovina and Macedonia, and finally the two republics - Serbia and Montenegro (9 and 23 December 1990) ${ }^{20}$.

The shape of the political scene at that time indicated - with a great probability - the future of the common state of the Southern Slavs. In Slovenia and Croatia the center-right parties won, defeating the post-communist left, while the national groups succeeded in two successive republics. The post-communist group won in Serbia and Montenegro (what is interesting, at the time of the elections to the Montenegrin parliament this party was still called the League of Communist of Montenegro) $)^{21}$.

The new (or rather - renewed) political elites began to change the structures of the supreme authority of republican power. Instead of the collegiate Presidium of the Republic, they started to create the president's office. Franjo Tudjman, leader of the winning Croatian Democratic Union, was elected chairman of the Presidium of the Socialist Republic of Croatia on 30 May $1990^{22}$. At the same time, intensive work was undertaken to

17 see M. J. Z a c hari a s, Rozpad Zwiazku Komunistów Jugosławii w 1990 r., ,, Dzieje Najnowsze: kwartalnik poświęcony historii XX wieku”, 2002, nr 3, s. 111-139 oraz D. A. D y ke r, The Degeneration of the Yugoslave Communist Party as a Managing Elite - a Familiar East European Story, [in:] Yugoslavia and After. A Study in Fragmentation, Despair and Rebirth, s. 48 et seq.

${ }^{18}$ see W. Walki ew i c z, Jugosławia. Byt wspólny i rozpad, Warszawa 2000; M. Wa l d e n b e rg, Rozbicie Jugosławii: od separacji Stowenii do wojny kosowskiej, Warszawa 2003; E. B u j w i d-K u r e k, Państwa pojugosłowiańskie. Szkice politologiczne, Kraków 2008; J. Wojn ic ki, Przeobrażenia ustrojowe państw postjugosłowiańskich (1990-2003), Pułtusk 2003; S. Wo j c i e c h ow s k i, Integracja i dezintegracja Jugosławii na przetomie XX i XXI wieku, Poznań 1998 oraz S. P. R a met, Balkan Babel. The Disintegration of Yugoslavia from the Death of Tito to Etnic War, Westwiew Press 1996.

${ }^{19}$ see J. Wojn i c k i, Proces instytucjonalizacji przemian ustrojowych w państwach postjugosłowiańskich, Warszawa 2007, p. 122.

${ }^{20}$ see K. Kry s i en i e1, Jugosławia na rozdrożu: wybory do władz republikańskich w 1990 roku, ,Studia Politicae Universitatis Silesiensis", T. 7, 2011, p. 158-181; J. Wojnicki, Alternacja władzy w państwach postjugosłowiańskich, [w:] Alternatywne sposoby głosowania a aktywizacja elektoratu, [red.] S. Grabowska, R. Grabowski, Rzeszów 2007; G. Swain and N. Swain, Eastern Europe Since 1945, Basinstoke 1998, p. 197.

${ }^{21}$ see J. Wiatr, Zmierzch systemu, Warszawa 1991; L. P odhoro de c ki, Jugosławia: dzieje narodów, państw i rozpad federacji; M. Ta n ty, Bałkany w XX wieku. Dzieje polityczne oraz Yugoslavia and After. A Study in Fragmentation, Despair and Rebirth; L. Hol m e s, Post-Communism. An Introduction, Duke University Press 1997; A. Ágh, The Politics of Central Europe, London 1998.

${ }^{22}$ see D. Bilandžić, Croatia between War and Independence, Zagreb 1991, p. 41 et seq.; D. P a vlič e vi ć, Historia Chorwacji; przekł. Ł. Danielewska, Poznań 2004, p. 511; K. K r y s i e n i e 1, System polityczny Republiki Chorwacji, Poznań-Chorzów 2007, p. 95 oraz L. J. C o h e n, Embattled democracy: post-communist Croatia in transition, [in:] Politics, Power and the Struggle for Democracy in South-East Europe, [ed.] K. Dawisha, B. Parrott, Cambridge University Press 1997, p. 80. 
develop a comprehensive constitutional law with the intention of leaving the federation and establishing an independent state. It was adopted at the last session of the Sabor on 21 December 1990 and it is known as Christmas Constitution ${ }^{23}$.

Under its 1990 constitution, Croatia operated a semi-presidential system until 2000 when it switched to a parliamentary system. Government powers in Croatia are divided into: legislative, executive and judiciary powers. The President of the Republic (Croatian: Predsjednik Republike) is the head of state, directly elected to a five-year term and is limited by the Constitution to a maximum of two terms. In addition to being the commander in chief of the armed forces, the president has the procedural duty of appointing the prime minister with the consent of the parliament, and has some influence on foreign policy. The government is headed by the Prime Minister, who has four deputy prime ministers and 16 ministers in charge of particular sectors of activity. As the executive branch, they are responsible for proposing legislation and a budget, executing the laws, and guiding the foreign and internal policies of the republic.

A referendum approving a new constitutional law was held in July in Serbia, the largest Yugoslav republic. The Constitution came into force on 28 September $1990^{24}$. It established the position of President in the Republic, that was elected in the general and direct election. The election were planned on 9 December $1990^{25}$.

The President of the Republic (Predsednik Republike) is the head of state and is elected by popular vote to a five-year term and is limited by the Constitution to a maximum of two terms. In addition to being the commander in chief of the armed forces, the president has the procedural duty of appointing the prime minister with the consent of the parliament, and has some influence on foreign policy. The seat of the presidency is Novi Dvor. The Government (Vlada) is composed of the prime minister and cabinet ministers. The Government is responsible for proposing legislation and a budget, executing the laws, and guiding the foreign and internal policies.

In Macedonia, the office of the President of the Republic was introduced on the basis of an amendment to the current constitution of the Republic made in January $1991^{26}$. As it stated in the amendment, the head of state was elected by the Republican Parliament, which in fact happened at the meeting on 27 January $1991^{27}$.

The new constitution of Macedonia was adopted on 17 September 1991. It described the position of president in the system of central state institutions in detail (at the same

${ }^{23}$ see Konstytucja Republiki Chorwacji, [red.] A. i L. Garliccy, Warszawa 1995; K. Sk ł a d o w s k i, System rządów w Republice Chorwacji, Łódź 2013, p. 53.

${ }^{24}$ see D. Miku cka-Wó j to w i z, Demokratyczna transformacja w Serbii i Chorwacji w latach 19902010, Kraków 2014, p. 77.

${ }^{25}$ see R. Th o m as, The Politics of Serbia, New York 1999, p. 74 oraz N. J. Mille r, A failed transition: the case of Serbia, [in:] Politics, Power and the Struggle for Democracy in South-East Europe, [ed.] K. Dawisha, B. Parrott, Cambridge University Press 1997, p. 158.

${ }^{26}$ see D. M. Perry, The Republic of Macedonia: finding its way, [in:] Politics, Power and the Struggle for Democracy in South-East Europe, p. 233.

27 see A. K o s e s ki, Macedonia: od republiki zwiazkowej do państwa unitarnego, [w:] i d e m, W bałkańskim kręgu, Pułtusk-Warszawa 2013; A. K o s e ski, Glówne problemy transformacji w Republice Macedonii (1991-2000), [w:] ibidem; P. O1s ze w s k i, Macedonia: historia i wspótczesność, Radom 2010; A. Polkowska, Macedonia, Wrocław 2000, p. 27. 
time changing the mode of presidential election to free election). The direct election of the President of the Republic took place in October $1994^{28}$.

Macedonia is a parliamentary democracy with an executive government composed of a coalition of parties from the unicameral legislature (Собрание, Sobranie) and an independent judicial branch with a constitutional court. The Assembly is made up of 120 seats and the members are elected every four years. The role of the President of the Republic is mostly ceremonial, with the real power resting in the hands of the President of the Government. The President is the commander-in-chief of the state armed forces and a president of the state Security Council. The President is elected every five years and he or she can be elected twice at most.

In December 1991 the Slovenian parliament passed the Constitution ${ }^{29}$. Constitutional regulations established a modified form of parliamentary regime, with the enhanced position of the Government, and especially the prime minister. This model has been based on German solutions originating from the Constitution of May 1949. The office of president was introduced into the state supreme government system. In November 1992, the first direct presidential elections took place. The former chairman of the Presidium of the Republic - Milan Kučan was the winner ${ }^{30}$.

Since the breakup of the former Yugoslavia, Slovenia has instituted a stable, multi-party, democratic political system, characterized by regular elections, a free press, and an excellent human rights record. However, Slovenia is the only former Communist state that has never carried out lustration. By Constitution of Slovenia the country is a parliamentary democracy and a republic. Within its government, power is shared between a directly elected president, a prime minister, and an incompletely bicameral legislature. The legislative body is composed of the 90-member National Assembly-which takes the lead on virtually all legislative issues-and the National Council, a largely advisory body composed of representatives from social, economic, professional, and local interests.

In March 1992 the inhabitants of Montenegro decided in a referendum to continue the common state (union) with Serbia ${ }^{31}$. On 27 April 1992, the Federal Republic of Yugoslavia was created. On the same day, the first constitution of this federal state was enacted ${ }^{32}$. The constitutional legislator introduced the office of president of the Federal Republic of Yugoslavia that was elected by the Federal Assembly, made up of the Citizens' Council

28 see I. S taw ow y-Kawka, Historia Macedonii, Wrocław 2000, p. 293; T. Gruj oski, Raspadot na SFRJ. Studija i cvedosztvo, Skopje 2003, p. 245; Konstytucja Republiki Macedonii, [red.] J. Jackowicz, Warszawa 1999.

${ }^{29}$ see Konstytucja Republiki Stowenii, [red.] P. Winczorek, Warszawa 1994.

${ }^{30}$ see P. P. R a m e t, Democratization in Slovenia-the second stage, [in:] Politics, Power and the Struggle for Democracy in South-East Europe, [ed.] K. Dawisha, B. Parrott, Cambridge University Press 1997, p. 206; J. G o w, C. C a r m i c h a 1, Slovenia and the Slovenep. A Small State and New Europe, London 2000, p. 135 et seq. oraz http://www2.gov.si/up-rs/2002-2007/bp-mk.nsf/ostalo/biografija.

${ }^{31}$ see M. D y mars ki, Odbudowa państwowości Czarnogóry - uwarunkowania historyczne $i$ współczesne, [w:] Bałkany Zachodnie między przeszłościa a przyszłością, [red.] P. Chmielewski, P. L. Szczesio, Łódź 2013, p. 397-410; W. Walk i e w i c z, Czarnogórców droga do niepodległości, [w:] ibidem, p. 443-460.

${ }^{32}$ see W. Walki ew i c z, Jugosławia. Byt wspólny i rozpad; M. Wal d e n b e rg, Rozbicie Jugosławii: od separacji Stowenii do wojny kosowskiej, Warszawa 2003; E. B u j w i d-K u r e k, Państwa pojugosłowiańskie. Szkice politologiczne, Kraków 2008; J. Wojni cki, Przeobrażenia ustrojowe państw postjugosłowiańskich (1990-2003), Pułtusk 2003. 
and Council of the Republics. At the same time anti-discrimination regulations in favour of a much smaller republic of Montenegro were introduced. Federal President and Prime Minister of the Federal Government could not come from the same republic. This record was in force until February 2003.

After the federation was reconstituted as a state union, the new Assembly of the State Union was created. It was unicameral and was made up of 126 deputies, of which 91 were from Serbia and 35 were from Montenegro. The Assembly convened in the building of the old Federal Assembly of FRY, which now houses the National Assembly of Serbia. In 2003, after the constitutional changes, a new President of Serbia and Montenegro was elected. Svetozar Marović was the first and last President of Serbia and Montenegro until its breakup in 2006.

In May 1992, president of the Federated Republic of Yugoslavia was elected. The candidate nominated by S. Miloševic was a writer - Dobric Čosić, popularizer of Serbian national idea since the $1960 \mathrm{~s}^{33}$. As a Serb political analyst remarked:

Indeed, the topmost position in the state depended heavily on the Milosevic party, which had a majority in the parliament, so the Serbian president was convinced of the possibility of manipulating federal authorities, especially when winners were the candidates he supported. It was his political mistake, because the story went differently ${ }^{34}$.

In June 1993, when the mentioned Serbian politician turned out to be somewhat independent from the leader of Serbia (taking the initiative to defuse the Bosnian conflict), the Federal Parliament recalled the first president of the Federal Republic of Yugoslavia ${ }^{35}$. A close associate of S. Milošević - Zoran Lilić was appointed the second president ${ }^{36}$.

In 1997, when the second legally permissible, Milošević's term as the president of the Republic of Serbia has passed, the politician decided to continue his political influence as president of the Federation ${ }^{37}$. The Federal Assembly amended the constitution by introducing direct presidential elections in July $2000^{38}$. The power of the head of state has not been changed, nor has been the structure of central institutions. The elections were carried out on September 24, $2000^{39}$. Opinions of the oppositional activists were rather cautious, especially taking into account their previous experience with the functioning of a state ruled by S. Milošević,. Political scientist Nebojš Popov declared in the early October:

we have lost too much time. Yugoslavia, and especially Serbia, are still moving away from the European community. That is why it is awe to even think what would happen if

33 see M. Korzeni ew ska-Wis zn i ew ska, Serbia pod rządami Slobodana Miloševicia: serbska polityka wobec rozpadu Jugosławii w latach dziewięćdziesiątych XX wieku, Kraków 2008, p. 143; M. Ta n ty, Bałkany w XX wieku, p. 351 oraz L. Holm e s, Jugosławia. Historia w zarysie, p. 231 oraz L. P o d h or o d e c k i, Jugosławia..., p. 205.

${ }^{34}$ see M. Kor zen i ew s k a-W is zn i ew s k a, Serbia pod rządami Slobodana Miloševicia, p. 142.

35 see R. Th o m a s, The Politics of Serbia, New York 1999, p. 156.

${ }^{36}$ see M. Kor ze ni e w s k a-W is zn i ew s k a, Serbia pod rządami Slobodana Miloševicia, p. 171; http:// arhiva.glas-javnosti.rs/arhiva/2000/05/11/srpski/P00051027.shtm

${ }^{37}$ see R. Thom a s, The Politics of Serbia, p. 336 oraz L. Holm es, Jugosławia. Historia w zarysie, p. 245 i M. Tanty, Bałkany w XX wieku, p. 359.

${ }^{38}$ see M. Korzeniews ka-Wis zni ew s ka, Serbia pod rządami Slobodana Miloševicia, p. 240 oraz L. Holm es, Jugosławia. Historia $w$ zarysie, p. 249.

39 see M. Korzeni ew sk a-W is zn i ew s ka, Serbia pod rządami Slobodana Miloševicia, p. 241 oraz L. Holm es, Jugosławia. Historia w zarysie, Kraków 2011, p. 249. 
we were to lose the victory again, as in 1996 when people went out into the streets, also because of the 'stolen votes', then in the local elections ${ }^{40}$.

In October 5, 2000 the outgoing president recognized his electoral failure. The president's office was taken over - after giving an appropriate vow -by Vojislav Koštunica, a candidate of the Serbian democratic opposition ${ }^{41}$. According to Ivan Cicak, a Balkan expert from Zagreb, the most important news in Serbia in October 2000 was that "Milosevic is over". Nobody so far has threatened his position. Kostunica can be either for cooperation with Europe or against it. In the latter case, he would become Milosevic's incarnation," adds Cicak. According to an activist of Serbian opposition Nenad Canak, Kostunica is not the providential man of Serbia, but only a man needed for a transitional period to remove Milosevic from power. Most of the Serbs, meanwhile, recall the nineteenth-century "prophecies"; according to them, the savior of Serbia will be "a man whose name sounds like the name of the place where he was born". The Kostunic family is from Kostunici ${ }^{42}$.

The last Yugoslav republic in which Presidential institutions were introduced was Montenegro. The Parliament passed a new constitutional law at its meeting on 8 February $1992^{43}$. The first direct presidential elections in that republic took place in December 1992 and confirmed the dominance of the post-communist politician - Momir Bulatovic ${ }^{44}$.

It is worth paying attention to a different internal situation in the last Yugoslav republic - Bosnia and Herzegovina. Because of its complex ethnic mosaic, it was called "Yugoslavia in miniature" 45

The constitution of 1974 , novelized at the beginning of 90 s, was there in force until $1996^{46}$. The text of the constitution of Bosnia and Herzegovina was part of a package of peace treaties developed by the European and American great powers in Dayton in November 1995. It was decided that the heads of state would be represented by a three-person Presidium composed of Muslims, Serbs and Croats elected in the general elections in the Muslim-Croatian Federation (two seats) and in the Republic of Serbia (one seat). The first election according to the above regulations was carried out in September $1996^{47}$.

While forming their own state systems, the new states created by the break-up of the Yugoslav federation could derive from several patterns. First of all: from their own national or political traditions (if any). Secondly, from the solutions of other European countries,

${ }^{40}$ see R. Bils k i, Godziny nadziei, [w;] R. B ils ki, Wielki post w osiemnastym batalionie, Sejny 2001, p. 228.

${ }^{41}$ see W. Walk iew i c z, Jugosławia. Państwa sukcesyjne, Warszawa 2009, p. 287.

${ }^{42}$ see M. Gr a c zy k, Nadzieja Serbii, ,Tygodnik Wprost”, nr 41, 2000.

${ }^{43}$ see M. Dy marsk i, Odbudowa państwowości Czarnogóry - uwarunkowania historyczne $i$ wspótczesne, [w:] Bałkany Zachodnie między przeszłościa a przyszłością, p. 397-410; W. Wa l k i e w i c z, Czarnogórców droga do niepodległości, [w:] ibidem, p. 443-460.

${ }^{44}$ see F. B i e b e r, Montegrin politics since the disintegration of Yugoslavia, [in:] Montegro in Transition, [ed.] F. B i e b e r, Baden Baden 2003, p. 29.

${ }^{45}$ see W. Walki ew ic z, Jugosławia. Państwa sukcesyjne, p. 255 et seq.

${ }^{46}$ see szerzej K. Kry s i e n i e 1, W cieniu Dayton: Bośnia i Hercegowina między etnokracją i demokracja konsocjonalna, Warszawa 2012.

47 see P. S o c h a c k i, Bośnia i Hercegowina 1995-2012: studium politologiczne, Toruń 2015; D. G ib a s-Krzak, Bośnia i Hercegowina: determinanty dziejów: pomiędzy Serbami, Chorwatami a supremacją Muzutmanów, Częstochowa 2016; K. Kry s i en i e 1, Ewolucja systemu politycznego Bośni i Hercegowiny w latach 1990-1995, [w:] Batkany Zachodnie między przeszłościa a przyszłością, p. 225-242. 
not only the Western consolidated democracies of the Federal Republic of Germany or the French Republic, but also other states undergoing the process of political transformation in the late 80's and 90's ${ }^{48}$. Thirdly, they could refer to the solutions that existed in the Yugoslav state in various historical periods, both the kingdom that survived until 1941 and the socialist state established in $1945^{49}$. It should be noted that the new states had different state traditions - Slovenia, Bosnia and Herzegovina and Macedonia did not have tradition of their own state until the 20th century. On the other hand, the Croatian experience was connected with the functioning of the Austro-Hungarian Monarchy, especially after the settlement with the Hungarians in 1868. Serbia and Montenegro had the richest state experience, however, it should be mentioned that these were the least democratic experiences ${ }^{50}$. As far as Western European democracies are concerned, the strongest traditions were found in the republics most closely related to Western civilization (Slovenia and Croatia). Generally speaking, politicians and constitutionalists from those countries had the choice of two well-tested models, parliamentary model and a one with more active presidency, although both were tested in a different socio-political reality. The first model in the rationalized version was in Germany after May 1949 and greatly strengthened the federal government's position and its head - the federal chancellor. In another embodiment, the above model was formed in Austria, which could have been an interesting experience for peoples living in the common Habsburg state. On the other hand, the second model with the strengthened constitutional position of president, was present in the French Republic, which has been known as 'fifth' since October $1958^{51}$.

There was a fundamental problem with referring to the Yugoslav tradition. This problem derived from the attitude of the Southern Slavic people to state system. On the contrary to the appearances, the Yugoslav tradition was not strong in Serbia (in the republic which fought the longest for the commonwealth) nor in Croatia (due to the nationality of Yugoslavian long-time leader Josip Broz). Some institutions referring to the self-government system (but in the sense of socio-economic and not territorial system) can be seen in the Republic of Slovenia (model of the second parliamentary chamber - State Council) or the Skupsztina system in the Republic of Macedonia ${ }^{52}$.

48 see B. Zawadzka, Zmiany systemu politycznego w ustawodawstwie państw Europy Środkowej i Wschodniej, Warszawa 1992; M. B a n k o w i c z, Transformacje konstytucyjnych systemów władzy państwowej w Europie Środkowej, Kraków 2010; A. Ág h, The Politics of Central Europe, p. 84 et seq.; T. K a ra k a m is ze v a, Izbori i izborni sistemi, Skopje 2004, p. 146 et seq.

49 see M. Wy rzy kow ski, Recepcja w prawie publicznym - tendencje rozwojowe konstytucjonalizmu w Europie Srodkowej i Wschodnej, „Państwo i Prawo”, nr 11, 1992; W. S o k ole w i c z, Nowa rola konstytucji w postsocjalistycznych państwach Europy, „Państwo i Prawo”, nr 10, 2000; T. Holm e s P., O metodzie zmian konstytucji w państwach Europy Wschodniej, „Państwo i Prawo”, nr 8, 1993.

${ }^{50}$ see B. Jelavich, Historia Bałkanów, tom II; M. Tanty, Bałkany w XX wieku; R. Crampton, The Balkans Since the Second World War, London 2002; G. Cas t te 11 a n, Histoire des Balkans XIV-XXe siècle, Paris 1991 .

51 see P. G e b e th n e r, Parlamentarne i prezydenckie systemy rządów (porównawcza analiza politologiczna), „Państwo i Prawo”, nr 7-8, 1994; J. Woj n i c k i, Parlamentaryzm czy semiprezydencjalizm. - Spór o wybór formy ustroju, [w:] Zagadnienia konstytucjonalizmu krajów Europy Środkowo-Wschodniej, [red.] T. M o 1daw a, Warszawa 2003, p. 90 et seq.; Konstytucyjne systemy rządów, [red.] M. Domagała, Warszawa 1997.

52 see P. Mikuli, System konstytucyjny Stowenii, Warszawa 2004; J. Wo j n i c k i, System konstytucyjny Macedonii, Warszawa 2009; Systemy polityczne państw bałkańskich, [red.] M. Podolak, T. Bichta, Lublin 2012. 
There is another thread that should also be considered: why the legislators introduced the president's office at the turn of the eighth and ninth decade of the twentieth century. In this case, there could be several aspects pointed out - firstly, the institutionalization of the strong authority of an individual. In the Balkan states there is a long and well-established tradition of strong monarchs (prince, king, tsar) or leader of the communist group (Tito casus after 1944 as the general secretary of the Communist Party of Yugoslavia and then League of Communists of Yugoslavia). It should be noted that all of the former Presidents of the Slavs were - except for Koštunica - less or more active members of the Communist Party. Secondly, in terms of democratic change, there was a stronger (example of Slovenia) or a weaker shade (other republics) of an appropriate constitutional form searched, for a state undergoing extensive political and economic transformations. The formation of new states, often under conditions of war, additionally forced the strengthening of executive power, often in the form of a presidential office ${ }^{53}$. Thirdly, the appearance of the president's office symbolized the systemic modernization of these states, the transition from a group of socialist states to democratic states. Fourthly, there was also an international approach - the partners of other European countries (and not only) were politicians holding identical political offices. Fifthly, it should be mentioned, especially in the context of the second factor, the widespread introduction of the direct mode of election of the head of state. It was supposed to strengthen the legitimacy of the politicians, that were often changing from the leader of the Communist Party to the president's office (Slobodan Milošević in Serbia, Milan Kučan in Slovenia, Momir Bulatović in Montenegro) ${ }^{54}$. According to the initiators of the transformation, it proved their democratic intentions. While making major political decisions they could rely on the idea of realization of the national interest expressed in the result of a presidential election. An important factor was, in both direct and a modified form, the model of the Yugoslav presidency associated with the name of Tito ${ }^{55}$.

The analysis of the relationship between legislative, executive, and judiciary powers in this group of states can be traced to two basic models, which, with minor or major internal problems, were established at the turn of the $80 \mathrm{~s}$ and $90 \mathrm{~s}$. The parliamentary model was indicated in the Slovenian case and, with some doubts, in the Macedonian case ${ }^{56}$. On the other hand, in the two republics in which the authority was taken over by strong

53 see A. Lijphart, Presidentialism and Majoritian Democracy: Theoretical Observations, [in:] Democracy and Transformations. Theories and East Central European Realities, [ed.] G. Szoboszlai, Budapeszt 1991; J. Linz, The Perils of Presidentialism, [in:] Parliamentary versus Presidential Government, [ed.] A. Lijphart, New York 1992; A. S te p a n, C. S k a c h, Modele konstytucyjne a umacnianie demokracji, "Państwo i Prawo", nr 4, 1994.

${ }^{54}$ see Stownik biograficzny Europy Środkowo-Wschodniej XX wieku, [red.] J. Kofman, W. Roszkowski, Warszawa 2005; V. S t a v a n o v ić, Milošević. Jedan epitaf, Zagreb 2002.

55 see A. Ágh, The Politics of Central Europe, p. 171 et seq.; Politics, Power and the Struggle for Democracy in South-East Europe, [ed.] K. Dawisha, B. Parrott, Cambridge University Press 1997; L. Holmes, Post-Communism. An Introduction, p. 72 et seq.

${ }^{56}$ see J. Wi atr, Stowenia - przyktad udanej transformacji, Warszawa 1998 oraz P. Mikuli, Prezydent Republiki Słowenii, [w:] Szkice o pozycji ustrojowej i statusie głowy państwa, [red.] M. Grzybowski, Kraków 2003, p. 89 et seq.; E. B u j w i d-K u re k, Pozycja głowy państwa w rozwiazaniach konstytucyjnych wybranych państw postjugostowiańskich, "Politeja", 2004, nr 2, p. 335 et seq.; P. Skarić, Sporedbeno i makedonsko ustavno pravo, Skopje 2004, p. 528. 
individuals - I mean Slobodan Milosevic and Franjo Tudjman - the system solutions were similar to those of the more active president (semi-presidential) ${ }^{57}$. The changes in Croatia and Serbia began after the alternation of power in 2000 and a slow move away from democratorship model.

It is important to note strong authoritarian tendencies in the Balkan states, manifested in the rule of powerful individuals, which is fostered not only by tradition and a difficult socioeconomic situation, but also by the significant role of the electronic media centered on the political leader (symbolized by the president's office as well as the head of government). Real power has not always been in institutions defined by constitutional rules, there was a considerable gap between the "real state" and the "formal state", which has characterized the Balkan reality for many years ${ }^{58}$.

Famous sociologist Jerzy Wiatr describes the following models of presidential leadership in the states that grew out of the "ruins" of the Yugoslav federation. Reformers of the system rooted in the political structures of the old system, Milan Kučan belongs to this group. He played a significant role in directing the party to the agenda of social and political reforms st the head of the structures of the Slovenian communists in the 1980s, winning the first head of state elections in April 1990, while his former group suffered a severe defeat in the parliamentary election. The second most serious role was played by politicians known as builders of nation states. This group includes Milan Kučan in Slovenia, Franjo Tudjman in Croatia, Alija Izetbegović in Bosnia and Herzegovina, Slobodan Milošević in Serbia or Kiro Gligorov in Macedonia ${ }^{59}$. As the Polish sociologist points out, the creation of a nation state meant, not only and not above all, the achievement of independence, international recognition, but also the correct relations with ethnic minorities and the formation of democratic and stable political institutions. Not all politicians have treated their missions in such a way as to refer to the examples of Slobodan Milosevic, Franjo Tudjana, or Alija Izetbegovic ${ }^{60}$. Other styles of presidential leadership have been noted by other researchers, for instance the active and passive model, by Tomasz Słom$\mathrm{ka}^{61}$, or the three key types of leadership by Przemyslaw Żukiewicz: conflict presidency, compromise presidency and harmless presidency. The following may be included in the first model: Slobodana Miloševic in Serbia, Franjo Tudjman in Croatia and Vojislav Koštunica in the Federal Republic of Yugoslavia, in the second model - Kiro Gligorov, Boris Trajkovski (both in Macedonia), Boris Tadic in Serbia or Milana Kučan in Slovenia, and to the third one - Stipe Mesic, Ivo Josipovic (both in Croatia), Filip Vujanovic (in Montenegro), Dobrica Čosic (in the Federal Republic of Yugoslavia), Svetozar Marovic

${ }^{57}$ see D. Miku ck k-W ój tow i c z, Demokratyczna transformacja w Serbii i Chorwacji w latach 19902010, Kraków 2014, p. 139 et seq.; N. Zak o š e k, Politički sustav Hrvatske, Zagreb 2002, p. 111; M. K a s a pov i ć, Izborni i starnački sustav Republike Hrvatske, Zagreb 1993, p. 58 et seq.; K. S kła d ow s k i, System rządów w Republice Chorwacji, p. 341 et seq.

58 see Between Authoritarianism and Democracy: Serbia, Montenegro, Croatia, vol. 1, [ed.] D. Vujadinović, Beograd 2003; Dijalozi o tranziciju u demokratiju, [priredio] R. Bubalo, Novi Sad 2005 oraz Demokratizacija i parlamentarizm v Vostoćnoj Evropie, Mockva 2003.

59 see J. J. Wi i tr, Europa pokomunistyczna. Przemiany państw i społeczeństw po 1989 roku, Warszawa 2006, p. 282.

${ }^{60}$ Ibidem.

${ }^{61}$ see T. Słomka, Prezydent Rzeczypospolitej Polskiej po 1989 roku: ujęcie porównawcze, Warszawa 2005, p. 214. 
(in Serbia and Montenegro), Branko Crvenkovski in Macedonia, Tomislav Nikolic in Serbia, Janez Drnovšek, Danilo Türk and Borut Pahor (all three in Slovenia) ${ }^{62}$.

While analyzing the post-Yugoslav countries' political systems (in the context of the position held by the presidents), it is necessary to refer to the current socio-political situation of these states. It allows to show the fascist or inadequate certain legal and political regulations in the functioning of the modern state. It also shows the centers of real state power, formed in addition to the formal political-constitutional order.

By 2008, Macedonia had the status of an informal leader in the process of integration with the EU and NATO, and - after Croatia - the fastest-reforming post-Yugoslav state (not counting Slovenia). Following the blocking of Macedonia's accession negotiations with the EU and its membership of NATO in connection with the dispute with Greece, the Macedonian authorities have, however, departed from reform policy to strengthen the autocratic system and consolidate society by referring to nationalist slogans ${ }^{63}$. The policy against the socio-political crisis in Macedonia undermined the credibility of the European institutions as a player that attaches a great importance to democratic standards and long-term stability. Instead of solving the problems of Macedonia by organizing negotiations with Greece and supporting further EU integration, the EU sought to reach a swift agreement, the implementation of which was uncertain from the beginning and gave a slight chance for a real and lasting democratization of the political system. Cooperation of the EU politicians with the Macedonian authorities in the field of migration also legitimized the undemocratic VMRO-DPMNE (The Internal Macedonian Revolutionary Organization - Democratic Party for Macedonian National Unity) government, weakening the opposition and civil society. The structural problems of Macedonia will, in the perspective of time, continue to deepen, and social and ethnic tensions remain a threat to the stability of the country ${ }^{64}$.

A similar trend has been observed in the recent past in the Republic of Croatia. Kolinda Grabar-Kitarović, the then candidate of the oppositional Croatian Democratic Union, won thanks to the transformation of the presidential election in January 2015 into a referendum on the policy of the center-left government. She succeeded in making economic policy - although it is not a prerogative of the head of state - the main theme of the election campaign, in blaming outgoing President Josipovic for the government activities and in taking advantage of social frustration associated with a six year recession and high unemployment (16.6\% Eurostat). Although Grabar-Kitarovic was a minister in the government of former Prime Minister Ivo Sanader (The Croatian Democratic Union) condemned, by highlighting her experience in working outside of Croatia (NATO, diplomatic missions), unambiguously presented herself as a representative of so called "cleaned" Croatian Democratic Union. While avoiding the expressive world-view declarations, she won the center-right voters ${ }^{65}$.

The complicated political and institutional situation was also characteristic for the neighboring Serbia, that was shaping its democratic system since autumn 2000. On 6 May 2012 all three: parliamentary, presidential and local elections were held in the Re-

${ }^{62}$ see P. Ż u k i e w i c z, Przywództwo prezydenckie w państwach Europy Środkowej i Wschodniej po 1989 roku. Analiza porównawcza, Toruń 2013, p. 284.

${ }^{63}$ see M. S z pa la, Macedonia: pozorna demokracja w cieniu kryzysów, „Komentarze OSW”, 01-04-2016.

64 Ibidem.

${ }^{65}$ see M. S zpala, Kolinda Grabar-Kitarović prezydentem Chorwacji, „Komentarze OSW”, 15-01-2015. 
public of Serbia,. None of the key political parties won a clear victory in the elections to the National Assembly. The conservative left-wing coalition of Tomislav Nikolic and his Serbian Progress Party (SNS) got 24\% and 73 seats, and the pro-European coalition "For a better life" formed around the Democratic Party (DS) of former President Boris Tadic reached $22 \%$ and respectively 67 seats. The coalition of the Serbian Socialist Party (SPS) the group of deceased Serb leader Slobodan Milosevic had 44 seats. The 250 members of the parliament also included 21 representatives of the nationalist Democratic Party of Serbia (DSS) and two liberal groups - the U.S. Serbian Republic (URS) and the Preokret party, which received respectively 20 and 16 seats. On the other hand, 9 seats in the parliament were won by the representatives of national minorities ${ }^{66}$. In the presidential election the representative of the nationalist group - Tomislav Nikolić won.

The total dominance of the Serbian Progressive Party (SNS) in the state institutions (President Tomislav Nikolić also derives from this group) is a serious test for young Serbian democracy. Prime Minister A. Vučić announced that he would not seek political change and that full executive power would only be used to introduce reforms that are needed on the way to the EU. This Serbian politician, however, has a tendency to "manually control" the state and use autocratic methods, and such understanding of effective governance may be on the contrary to EU requirements for the construction of stable and democratic state institutions ${ }^{67}$.

Strong non-democratic tendencies have also occurred in Montenegro, a country with short democratic traditions in the last century. At the parliamentary election in Montenegro on 16 October 2016, with the attendance of 71\%, the Democratic Party of Socialists (DPS), ruling from 1991 and headed by Prime Minister Milo Djukanović won. According to preliminary results, DPS received $41 \%$ of the votes (36 seats out of 81 seats). allies of the DPS - Social Democrats of Montenegro (SD) with two seats and the main opposition groups: Proserbska and Pro-Russian Front Democratic coalition (DF, 18 seats), eclectic coalition Key (9 seats), centre-left Democratic Montenegro ( 8 seats) and the Social Democratic Party (SDP, 4 seats) will also be in the Assembly of the Republic. The parties of national minorities (Bosnian, Albanian and Croatian) have won four seats. In the election campaign the opposition pointed to socio-economic problems (high unemployment) and authoritarian clan relations in the Montenegrin elite power symbolized since 1991 by Djukanović ${ }^{68}$. On the night before the Montenegrin election, the police arrested 20 Serbian citizens accused of planning terrorist acts and organizing a coup combined with an attack on Milo Djukanović. These arrests were publicly criticized by Serbian Prime Minister Aleksandar Vučić, suggesting that the actual reasons for detention were different from those of the official authorities. Due to the police action, four opposition groups did not recognize the results of the election, as opposed to the EU and NATO representatives ${ }^{69}$.

The detention of a group of Serbs accused of planning a coup on the eve of the parliamentary election was seen by the observers as a part of the DPS election campaign. This was proved by the fact that the head of the Ministry of Foreign Affairs (outside the DPS)

${ }^{66}$ see M. S z pala, Potrójne wybory w Serbii nie zmieniaja proeuropejskiego kursu, „Komentarze OSW”, 09-05-2012.

${ }^{67}$ see M. S z pala, Wybory w Serbii: petnia władzy dla Vučicia, ,Komentarze OSW”, 14-03-2014.

${ }^{68}$ see M. S e roka, Wybory parlamentarne w Czarnogórze, „Komentarze OSW”, 19-10-2016.

69 Ibidem. 
was not informed about the operations controlled by Djukanovic's police and special service officers. It is possible that the Serbs planned actions designed to induce social unrest in connection with the elections (their alleged leader is linked to the radical nationalist and pro-Russian movement of Zavetnici). They were most likely observed by the Montenegrin service, which immediately after being detained were able to give the personal details of the members of the group ${ }^{70}$.

The formation of the president's office in the post-Yugoslav countries was a complicated and dramatic process of shaping one's own states. This was probably the key element of the systemic transformation of the early 1990s. It was even more important than democratic and market changes in the socio-economic sphere (except Slovenia). The former leaders of the republican Communist parties occupied the presidential offices (the casus of Slovenia, Serbia and Montenegro). The Slovenian case was different from the other two on the scale of political and systemic changes. The advancement of democratic change in Slovenia over the years has been an unsurpassed model for other states created "on the rubble" of the Yugoslav federation ${ }^{71}$. In a few cases (Croatia, Bosnia and Herzegovina) the leaders of nationalist groups gained mass popularity and took over the influence on further events in their republics.

It should be noted that the establishment of the president's office in the early 1990s was not conducive to an in-depth analysis of the governance systems to be established in the Balkan Peninsula. One exception was Slovenia - and to a lesser extent - Macedonia ${ }^{72}$. The presidential tradition of Josip Broz-Tito was the only pattern of presidential tradition in the area discussed. The first president of an independent Croatian state referred directly to this frame and content. As noted by a Polish expert on the Balkan region:

It is important to emphasize this matter of all post-Yugoslav politicians that they, like women, were and are fascinated by Josip Broz Tito, even if they do not realize it. This was particularly evident in the example of Franjo Tudjman, who dressed in tailor-made uniforms: admiral, air, land forces, and who tried to imitate, unsuccessfully though, his charismatic great friend Josip Broz Tito ${ }^{73}$.

\section{Bibliography}

A. Ágh, The Politics of Central Europe, London 1998

M. Bankowicz, Transformacje konstytucyjnych systemów władzy państwowej w Europie Środkowej, Kraków 2010

Between Authoritarianism and Democracy: Serbia, Montenegro, Croatia, vol. 1, [ed.] D. Vujadinović, Beograd 2003

A. Biagini, F. Guida, Pót wieku realnego socjalizmu, Rzeszów 1998

F. Bieber, Montegrin politics since the disintegration of Yugoslavia, [in:] Montegro in Transition, [ed.] F. Bieber, Baden Baden 2003

D. Bilandžić, Craao War and Independence, Zagreb 1991

\footnotetext{
70 Ibidem.

71 see Democratization Processes in Poland and Slovenia: Comparative Study, [ed.] A. Turska-Kawa, M. Haček, Ljubljana 2016.

72 Ibidem.

73 see A. Ko s e ski, op. cit., p. 100.
} 
D. Bilandžić, Historija Socijalističke Federativne Republike Jugoslavije. Glavni procesi 1918-1985, Zagreb 1985

R. Bilski, Godziny nadziei, [w:] R. Bilski, Wielki post w osiemnastym batalionie, Sejny 2001

Z. Brzeziński, Jedność i konflikty, Londyn 1964

E. Bujwid-Kurek, Państwa pojugosłowiańskie. Szkice politologiczne, Kraków 2008

E. Bujwid-Kurek, Pozycja głowy państwa w rozwiazaniach konstytucyjnych wybranych państw postjugostowiańskich, "Politeja", 2004

G. Casttellan, Histoire des Balkans XIV-XXe siècle, Paris 1991

J. Ciemniewski, System delegacki na tle ewolucji ustroju politycznego Socjalistycznej Federacyjnej Republiki Jugosławii, Wrocław 1988

L. J. Cohen, Embattled democracy: postcommunist Croatia in transition, [in:] Politics, Power and the Struggle for Democracy in South-East Europe, [ed.] K. Dawisha, B. Parrott, Cambridge University Press 1997

R. Crampton, The Balkans Since the Second World War, London 2002

K. Čavoški, Tito. Tehnologika vlasti, Beograd 1990

Democratization Processes in Poland and Slovenia: Comparative Study, [ed.]A. Turska-Kawa, M. Haček, Ljubljana 2016

Demokratizacija i parlamentarizm v Vostoćnoj Evropie, Mockva 2003

Dijalozi o tranziciju u demokratiju, [priredio] R. Bubalo, Novi Sad 2005

D. A. Dyker, The Degeneration of the Yugoslave Communist Party as a Managing Elite - a Familiar East European Story, [in:] Yugoslavia and After. A Study in Fragmentation, Deaspair and Rebirth, [ed.] D. A. Dyker and I. Vejvoda, London and New York 1996

M. Dymarski, Odbudowa państwowości Czarnogóry - uwarunkowania historyczne i współczesne, [w:] Bałkany Zachodnie między przeszłością a przyszłościa, [red.] P. Chmielewski, S. L. Szczesio, Łódź 2013

J. Dżordzewicz, Ustrój państwowy Federacyjnej Ludowej Republiki Jugosławii, [w:] Ekonomia i polityka Jugostawii. Zbiór artykułów, Warszawa 1957

F. Fejtö, A History of the People's Democracies. Eastern Europe Since Stalin, New York, Washington, London 1971

S. Gebethner, Parlamentarne i prezydenckie systemy rządów (porównawcza analiza politologiczna), „Państwo i Prawo”, nr 7-8, 1994

D. Gibas-Krzak, Bośnia i Hercegowina: determinanty dziejów: pomiędzy Serbami, Chorwatami a supremacją Muzulmanów, Częstochowa 2016

J. Gow, C. Carmichael, Slovenia and the Slovenes. A Small State and New Europe, London 2000

M. Graczyk, Nadzieja Serbii, „Tygodnik Wprost”, nr 41 z 2000

T. Grujoski, Raspadot na SFRJ. Studija i cvedosztvo, Skopje 2003

L. Holmes, Jugostawia. Historia w zarysie, Kraków 2011

L. Holmes, Post-Communism. An Introduction, Duke University Press 1997

S. T. Holmes, O metodzie zmian konstytucji w państwach Europy Wschodniej, „Państwo i Prawo”, nr 8, 1993

B. Jelavich, Historia Bałkanów, tom drugi, wiek XX, Kraków 2005

R. D. Kaplan, Bałkańskie upiory. Podróż przez historię, Wołowiec 2010

T. Karakamiszeva, Izbori i izborni sistemi, Skopje 2004

M. Kasapović, Izborni i starnački sustav Republike Hrvatske, Zagreb 1993

Konstytucja Republiki Chorwacji, [red.] A. i L. Garliccy, Warszawa 1995

Konstytucja Republiki Macedonii, [red.] J. Jackowicz, Warszawa 1999

Konstytucja Republiki Stowenii, [red.] P. Winczorek, Warszawa 1994

Konstytucyjne systemy rządów, [red.] M. Domagała, Warszawa 1997 
M. Korzeniewska-Wiszniewska, Serbia pod rządami Slobodana Miloševicia: serbska polityka wobec rozpadu Jugostawii w latach dziewięćdziesiatych XX wieku, Kraków 2008

A. Koseski, Gtówne problemy transformacji w Republice Macedonii (1991-2000), [w:] W bałkańskim kręgu, Pułtusk-Warszawa 2013

A. Koseski, Macedonia: od republiki związkowej do państwa unitarnego, [w:] W bałkańskim kręgu, Pułtusk-Warszawa 2013

A. Koseski, $W$ bałkańskim tyglu, Pułtusk 2002

K. Krysieniel, Ewolucja systemu politycznego Bośni i Hercegowiny w latach 1990-1995, [w:] Batkany Zachodnie między przeszłościa a przyszłością, [red.] P. Chmielewski, S. L. Szczesio, Łódź 2013

K. Krysieniel, Jugosławia na rozdrożu: wybory do władz republikańskich w 1990 roku, „Studia Politicae Universitatis Silesiensis", T. 7 z 2011

K. Krysieniel, System polityczny Republiki Chorwacji, Poznań-Chorzów 2007

K. Krysieniel, W cieniu Dayton: Bośnia i Hercegowina między etnokracją i demokracją konsocjonalna, Warszawa 2012

J. Linz, The Perils of Presidentialism, [in:] Parliamentary versus Presidential Government, [ed.] A. Lijphart, New York 1992

A. Lijphart, Presidentialism and Majoritian Democracy: Theoretical Observations, [in:] Democracy and Transformations. Theories and East Central European Realities, [ed.] G. Szoboszlai, Budapeszt 1991

D. Mikucka-Wójtowicz, Demokratyczna transformacja w Serbii i Chorwacji w latach 1990-2010, Kraków 2014

P. Mikuli, Prezydent Republiki Stowenii, [w:] Szkice o pozycji ustrojowej i statusie głowy państwa, [red.] M. Grzybowski, Kraków 2003

P. Mikuli, System konstytucyjny Stowenii, Warszawa 2004

N. J. Miller, A failed transition: the case of Serbia, [in:] Politics, Power and the Struggle for Democracy in South-East Europe, [ed.] K. Dawisha, B. Parrott, Cambridge University Press 1997

E. Mizerski, Jugosłowiański system przedstawicielski 1918-1990 (w zarysie), Toruń 1999

P. Olszewski, Macedonia: historia i wspótczesność, Radom 2010

D. Pavličević, Historia Chorwacji, przekł. Ł. Danielewska, Poznań 2004

D. M. Perry, The Republic of Macedonia: finding its way, [in:] Politics, Power and the Struggle for Democracy in South-East Europe, [ed.] K. Dawisha, B. Parrott, Cambridge University Press 1997

L. Podchorodecki, Jugosławia. Dzieje narodów, państw i rozpad federacji, Warszawa 2000

Politics, Power and the Struggle for Democracy in South-East Europe, [ed.] K. Dawisha, B. Parrott, Cambridge University Press 1997

A. Polkowska, Macedonia, Wrocław 2000

S. P. Ramet, Balkan Babel. The Disintegration of Yugoslavia form the Death of Tito to Etnic War, Westwiew Press 1996

S. P. Ramet, Democratization in Slovenia-the second stage, [in;] Politics, Power and the Struggle for Democracy in South-East Europe, [ed.] K. Dawisha, B. Parrott, Cambridge University Press 1997

D. Rusinov, The Yugoslav Experiment 1948-1974, Berkeley and Los Angeles 1978

M. Seroka, Wybory parlamentarne w Czarnogórze, „Komentarze OSW”, 19-10-2016

S. Skarić, Sporedbeno i makedonsko ustavno pravo, Skopje 2004

K. Składowski, System rządów w Republice Chorwacji, Łódź 2013

T. Słomka, Prezydent Rzeczypospolitej Polskiej po 1989 roku: ujęcie porównawcze, Warszawa 2005 Stownik biograficzny Europy Środkowo-Wschodniej XX wieku, [red.] J. Kofman, W. Roszkowski, Warszawa 2005 
S. Sochacki, Bośnia i Hercegowina 1995-2012: studium politologiczne, Toruń 2015

R. Staar, Communist Regimes in Eastern Europe, Stanford 1982

V. Stavanović, Milošević. Jedan epitaf, Zagreb 2002

I. Stawowy-Kawka, Historia Macedonii, Wrocław 2000

A. Stepan, C. Skach, Modele konstytucyjne a umacnianie demokracji, „Państwo i Prawo”, nr 4, 1994

Systemy polityczne państw bałkańskich, [red.] M. Podolak, T. Bichta, Lublin 2012

G. Swain and N. Swain, Eastern Europe Since 1945, Basinstoke 1998

M. Szpala, Kolinda Grabar-Kitarović prezydentem Chorwacji, „Komentarze OSW”, 15-01-2015

M. Szpala, Macedonia: pozorna demokracja w cieniu kryzysów, „Komentarze OSW”, 01-04-2016

M. Szpala, Potrójne wybory w Serbii nie zmieniaja proeuropejskiego kursu, „Komentarze OSW”, 09-05-2012

M. Szpala, Wybory w Serbii: petnia władzy dla Vučicia, , Komentarze OSW”, 14-03-2014

T. Szymczak, Ewolucja instytucji prezydenta w socialistycznym prawie państwowym, Łódź 1976,

T. Szymczak, Organy władzy i administracji europejskich państw socjalistycznych, Warszawa 1970

M. Tanty, Batkany w XX wieku. Dzieje polityczne, Warszawa 2003

R. Thomas, The Politics of Serbia, New York 1999

Ustawa o podstawach ustroju spolecznego i politycznego Federacyjnej Ludowej Republiki Jugostawii z 13 stycznia 1953 roku, [w:] Konstytucja Federacyjnej Ludowej Republiki Jugosławii, Warszawa 1957

I. Vejvoda, Yugoslava 1945-1991-from Decentralization Without Democracy to Dissolution, [in:] Yugoslavia and After. A Study in Fragmentation, Deaspair and Rebirth, [ed.] D. A. Dyker and I. Vejvoda, London and New York 1996

M. Waldenberg, Rozbicie Jugostawii: od separacji Stowenii do wojny kosowskiej, Warszawa 2003

W. Walkiewicz, Czarnogórców droga do niepodległości, [w:] Bałkany Zachodnie między przeszłościa a przyszłościa, [red.] P. Chmielewski, S. L. Szczesio, Łódź 2013

W. Walkiewicz, Jugosławia. Wspólny byt i rozpad. Historia państw świata w XX wieku, Warszawa 2000

W. Walkiewicz, Jugosławia. Państwa sukcesyjne, Warszawa 2009

J. R. Wegs, R. Ladrech, Europa po 1945 roku. Zarys historii, Warszawa 2008

J. J. Wiatr, Europa pokomunistyczna. Przemiany państw i społeczeństw po 1989 roku, Warszawa 2006

J. J. Wiatr, Stowenia - przykład udanej transformacji, Warszawa 1998

J. J. Wiatr, Zmierzch systemu, Warszawa 1991

S. Wojciechowski, Integracja i dezintegracja Jugosławii na przełomie XX i XXI wieku, Poznań 1998

J. Wojnicki, Alternacja władzy w państwach postjugosłowiańskich, [w:] Alternatywne sposoby głosowania a aktywizacja elektoratu, [red.] S. Grabowska, R. Grabowski, Rzeszów 2007

J. Wojnicki, Parlamentaryzm czy semiprezydencjalizm. Spór o wybór formy ustroju, [w:] Zagadnienia konstytucjonalizmu krajów Europy Środkowo-Wschodniej, [red.] T. Mołdawa, Warszawa 2003

J. Wojnicki, Przeobrażenia ustrojowe państw postjugostowiańskich (1990-2003), Pułtusk 2003

J. Wojnicki, System konstytucyjny Macedonii, Warszawa 2009

R. L. Wolff, Balkans in Our Times, Cambridge, Massachusetts 1956

M. Wyrzykowski, Recepcja w prawie publicznym - tendencje rozwojowe konstytucjonalizmu w Europie Srodkowej i Wschodnej, „Państwo i Prawo”, nr 11, 1992

M. J. Zacharias, Komunizm, federacja, nacjonalizmy. System władzy w Jugosławii 1943-1991. Powstanie, przeksztatcenia, rozkład, Warszawa 2004

M. J. Zacharias, Rozpad Związu Komunistów Jugosławii w 1990 roku, ,, Dzieje Najnowsze. Kwartalnik poświęcony historii XX wieku”, 2002, nr 3 
M. J. Zacharias, Ustrój Jugosławii w latach 1974-1980: przestanki dezintegracji i późniejszego rozpadu państwa, ,, Studia z Dziejów Rosji i Europy Środkowo-Wschodniej”, T. 36 z 2001 r.

N. Zakošek, Politički sustav Hrvatske, Zagreb 2002

B. Zawadzka, Zmiany systemu politycznego w ustawodawstwie państw Europy Środkowej i Wschodniej, Warszawa 1992

E. Zieliński, Skupsztina SFRJ, Warszawa 1978

P. Żukiewicz, Przywództwo prezydenckie w państwach Europy Środkowej i Wschodniej po 1989 roku. Analiza porównawcza, Toruń 2013

\section{Jacek Wojnicki}

\section{The Evolution of the Presidency in the post-Yugoslav Countries in the 1990s - the Non-institutional or Institutional Element of the Democratic System}

\section{Summary}

This article is devoted to the analysis of the formation of state leadership in the states created after the breakup of the Yugoslav federation. Presidency was quite a new political solution, it has not occurred during the first Yugoslavia (1918-1941) nor, for obvious reasons, before World War I (lack of the state system, or the monarchical form of state - the cases of Serbia and Montenegro). The formation of new political and social institutions at the beginning of the 1990s was related to the functioning of the Yugoslav state on the one hand, and on the other hand to the observation and perception of external solutions, which did not always fit in the political system of a Balkan state.

Keywords: presidency, postcommunist states, desintegration of Yugoslavia, democratization, authoritarian. 